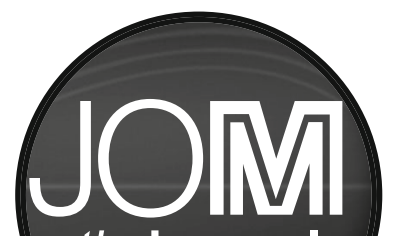

thejournal

\title{
2016 editorial calendar
}

\section{July 2016}

Theme: Manufacturing

- Surface Engineering via Additive Manufacturing

- Shaping, Forming, and Modeling of Advanced HighStrength Steels

- Metal- and Polymer-Matrix Composites II (invited) Manuscripts Due: Deadline Passed

\section{August 2016}

Theme: Big Data and Modeling

- Building a Materials Data Infrastructure

- Big Data and Data Analytics for Structural and Functional Materials

- CFD Modeling and Simulation in Materials Processing

- Driving Discovery: Integration of Multi-Modal Imaging and Data Analysis (invited)

- Archaeomaterials (invited)

Manuscripts Due: Deadline Passed

\section{September 2016}

Theme: Environment and Recycling

- Slag Metallurgy and Metallurgical Waste Recycling

- Progress with Lead-Free Solders

- Recent Advances in Forest Products Research and Development

- Aluminum: Recycling and Environmental Issues

- Towards Materials Resource Sustainability

Manuscripts Due: Deadline Passed

\section{October 2016}

Theme: Energy

- Advanced Materials for Fuel Cell and Battery Applications

- Modeling of Energy Processes

- Modeling Nuclear Fuel Performance

- Lithium Metals and Chemical Extraction and Processing

- Alloys and Compounds for Thermoelectrics

Manuscripts Due: Deadline Passed

\section{November 2016}

Theme: Materials for Extreme Environments

- High-Temperature In-Situ Micro/Nano Mechanical Testing

- Advances in High-Temperature Alloys

- Refractory Metals that Melt Above $1850^{\circ} \mathrm{C}$

- Biomaterials for Healthcare: Part II

Manuscripts Due: June 15, 2016

\section{December 2016}

Theme: Alloy Production and Corrosion

- Fe Alloys: Production and Metallurgical Aspects

- Aluminum: Cast Shop and Alloys

- Corrosion of Materials in Physiological Environments

- Advances and Achievements in In-Situ Analysis of Corrosion and Structure-Property Relationship in $\mathrm{Mg}$ and Mg Alloys

Manuscripts Due: July 15, 2016

\section{Coming in July: The 201 \\ January: Applying Materials Science and Engineering \\ February: Production and Characterization}

March: Additive Manufacturing

April: Materials Processing

May: Design and Manufacturing

June: Progress in Materials Science

\section{JOM Editorial Calendar}

July: Functional Materials

August: Extreme Environments

September: Environment and Recycling

October: Metallurgy and Processing

November: High-Entropy Alloys

December: Energy Applications 


\section{advisors and guest editors}

\author{
Amit Pandey \\ Advanced Characterization, Testing \\ $\&$ Simulation Committee \\ Sinn-wen Chen \\ Alloy Phases Committee \\ Dmitry Eskin and Pascal Lavoie \\ Aluminum Committee \\ Candan Tamerler \\ Biomaterials Committee \\ Fadi Abdeljawad and Stephen Foiles \\ Chemistry \& Physics of Materials \\ Committee \\ Muralidharan Paramsothy, \\ Dirk Lehmhus, and James Njuguna \\ Composite Materials Committee \\ Bala Radhakrishnan \\ Computational Materials Science \& \\ Engineering Committee \\ Vilupanur A. Ravi \\ Corrosion \& Environmental Effects \\ Committee \\ Babak Arfaei \\ Electronic Packaging \& Interconnection \\ Materials Committee \\ Geoff Brooks \\ Energy Committee
}

\author{
Xiaochuan Lu \\ Energy Conversion \& Storage Committee \\ Chantal Sudbrack \\ High Temperature Alloys Committee \\ Takanari Ouchi \\ Hydrometallurgy \& Electrometallurgy \\ Committee
}

Terry Wong

ICME Committee

Dmytro Orlov

Magnesium Committee

Orlando Rios

Magnetic Materials Committee

Jian Li

Materials Characterization

Committee

Marian S. Kennedy, Suveen

Mathaudhu, and Brad Boyce

Mechanical Behavior of Materials

Committee

Terry Xu and Jung-Kun Lee

Nanomaterials Committee

Joseph Jakes

Nanomechanical Materials Behavior

Committee

Ramprashad Prabhakaran

Nuclear Materials Committee
Amy Clarke

Phase Transformations Committee

$$
\begin{gathered}
\text { Ma Qian } \\
\text { Powder Materials Committee }
\end{gathered}
$$

Ed Herderick and Laurentiu Nastac

Process Technology \& Modeling

Committee

Zhiwei Peng and Dean Gregurek Pyrometallurgy Committee

Randy Kirchain

Recycling \& Environmental

Technologies Committee

Todd Leonhardt

Refractory Metals \& Materials

Committee

Mark Stoudt

Shaping \& Forming Committee

Mohsen Asle Zaeem

Solidification Committee

Narendra Dahotre, Benjamin Boesl, and Hitesh Vora

Surface Engineering Committee

Roger Narayan

Thin Films \& Interfaces Committee

Peter C. Collins

Titanium Committee

\section{INVITED GUEST EDITORS}

Patrick Bowen

Magnesium-Based Biodegradable Implants

Matthias Militzer

Phase Transformations of

Materials 2015
Frank Gayle

Summit on Integrated Manufacturing and Materials Innovations

Jonathan Madison

ICME 2015 World Congress

Vilupanur A. Ravi

Archaeomaterials
Nikhil Gupta

Metal- and Polymer-Matrix Composites II

Charudatta Phatak

Driving Discovery: Integration of Multi-Modal Imaging and Data Analysis

Anyone wishing to publish in JOM should follow the guidelines established

in the JOM Instructions for Authors, which features detailed information on

communication, manuscript preparation, and publication procedures.

The Instructions for Authors are available on the JOM website at jom.tms.org.

For More Information Contact: Telephone: (724) 776-9000 ext. 228 e-mail: jom @tms.org 